\title{
Fertility, female labor force participation, and the demographic dividend
}

\author{
David E. Bloom • David Canning • Günther Fink • \\ Jocelyn E. Finlay
}

Published online: 5 May 2009

(C) Springer Science+Business Media, LLC 2009

\begin{abstract}
We estimate the effect of fertility on female labor force participation in a panel of countries using abortion legislation as an instrument for fertility. We find that removing legal restrictions on abortion significantly reduces fertility and estimate that, on average, a birth reduces a woman's labor supply by almost 2 years during her reproductive life. Our results imply that behavioral change, in the form of increased female labor supply, contributes significantly to economic growth during the demographic transition when fertility declines.
\end{abstract}

Keywords Fertility · Labor supply · Demographic dividend

JEL Classification $\quad \mathrm{J} 13 \cdot \mathrm{J} 22 \cdot \mathrm{O} 15$

\section{Introduction}

During the demographic transition declines in mortality set of a population explosion and, without reductions in fertility, population growth may swamp available fixed factors such as land (the Malthusian model) and even reproducible factors such as physical capital (the Solow model). However, this Malthusian trap can be avoided if fertility declines. Technological progress can increase the return to human capital and this can in turn lead to a reduction in fertility as families choose smaller family size with increased investments in each child (Galor and Weil 1999, 2000). Fertility reduction in this framework contributes to economic growth by increasing the ratio of land and physical capital to labor, and by allowing increased investment in human capital. There are several theories on how the demographic transition has affected economic development (Galor 2005) and it should be noted that even with a fixed factor such as land increasing returns to scale in the production of physical or human capital may allow population growth to go hand in hand with rising income levels if these capital goods can be used to increase mechanization and efficiency so as to overcome any diminishing returns in agriculture (Becker et al. 1999; Canning 1988).

D. E. Bloom $(\bowtie) \cdot$ D. Canning · G. Fink · J. E. Finlay

Program on the Global Demography of Aging, Harvard School of Public Health, Harvard University, Boston, MA, USA 
As well as affecting capital intensity, fertility has effects on the population age structure. Smaller birth cohorts decrease youth dependency ratios and mechanically increase output per capita if labor force participation rates among the working age population remain unchanged. This change in age structure generates a demographic dividend which can help explain crosscountry variation in the growth of per capita income (Bloom et al. 2003; Bloom and Freeman 1986; Bloom and Williamson 1998; Brander and Dowrick 1994; Kelley and Schmidt 1995).

In addition to creating these age structure effects, demographic change may also lead to behavioral change. Lower mortality and longer life spans may affect retirement and savings decisions (Bloom et al. 2003, 2007). Fertility reductions can free up time from child care and can increase female labor supply, as well as investments in each child's health and education.

In this paper we focus on the effect of fertility reductions on female labor force participation. We use a panel of 97 countries over the period 1960-2000 to examine the effect of fertility on labor force participation by women during their fertile years. We argue that the effects of fertility reduction on female labor force participation are large, and this effect can contribute significantly to a takeoff in economic growth during the demographic transition when fertility rates are falling.

Studies of the behavioral response to changes in fertility are complicated by issues of endogeneity, and identifying the direction of causality is challenging (Browning 1992; Rosenzweig and Schultz 1985). Several different approaches have been used to identify the causal effect of fertility changes on behavioral outcomes. In microeconomic studies it is common to use twins, or the sex composition of previous births as factors that produce exogenous variation in fertility (e.g. Angrist and Evans 1998; Rosenzweig and Wolpin 1980). Changes in legislation have also been used as instruments for fertility. Legalization of abortion in the United States led to a decrease in fertility (Klerman 1999; Levine et al. 1999). The fertility decline induced by these changes in abortion laws led to an increase in the labor force participation of black women (Angrist and Evans 1996). State-level variations in legislation on access to the contraceptive pill in the United States have been used as instrument for fertility, finding an effect of fertility on female labor force participation (Bailey 2006).

In our analysis we use country-level abortion legislation as an instrument for fertility. We estimate that moving from the most restrictive legal constraints, with abortion being illegal in all circumstances, to the most unrestricted, with abortion being available on demand, lowers the total fertility rate by about 0.4 children per woman, on average. While this is quite a large effect it is consistent with the evidence (Henshaw et al. 1999) that, worldwide, around $26 \%$ of pregnancies end in abortion, and abortion is a common method of avoiding childbirth, in both developed and developing countries, when available.

A difficulty with using legal changes as instruments is that legislation itself may reflect broader trends in society that are also correlated with female labor force participation. Our key identifying assumption is that while the level and time trend in restrictions on abortion may reflect social forces, the exact timing of legal changes is exogenous. We discuss the plausibility of this identifying assumption in more detail below.

As a framework for our empirical analysis, we develop a simple theoretical model of female labor supply and fertility. In this model, female labor supply is a function of the wage rates of men and women, the infant mortality rate, the type of residence (urban versus rural), as well as the woman's fertility choice. The wages of men and women have income and substitution effects on the labor-leisure decision. High infant mortality rates reduce the number of surviving children and thus the time required for child care. ${ }^{1}$ An important additional factor

1 The opposite might be true for child morbidity, which we do not model explicitly here. Since high-mortality environments typically also have high morbidity, the total effect of child health on parental time requirement would be ambiguous in a model that incorporated both mortality and morbidity. 
which we model explicitly is the share of the population living in urban areas. Mammen and Paxson (2000), expanding on work by Goldin (1995), find the relationship between female labor force participation rates and per capita income around the world to be U-shaped. In poor, agricultural economies, where most households live in rural areas, female participation is high. In rural areas family responsibilities and agricultural work can be combined; the household is both a consumption unit and a production unit. Female participation is lowest in urbanized, middle-income countries. The separation of home and work environments in urban areas can make it difficult to combine raising a family with working, contributing to lower participation rates. Female participation rates are again high in high-income countries. In these countries women are highly educated, so the opportunity cost of exiting the workforce for childcare is high; female labor force participation rates are high and fertility rates are low in this environment. We control for the level of urbanization in our theory and empirical specification.

Our results imply that abortion laws are predictive of fertility and that higher fertility reduces female labor force participation of women during their fertile years. On average, we find that each additional child reduces female labor force participation by between 5 and 10 percentage points for women between the ages of 20 and 44. Aggregating these estimates over the reproductive life of a representative woman, this implies that each birth reduces total labor supply by about 1.9 years per woman.

During the demographic transition total fertility rates often fall by roughly four births per woman. Our analysis suggests that this fertility reduction increases total female labor supply by around 18 percentage points ( 8 additional years out of a potential lifetime supply of around 45 years). Under a standard Cobb-Douglas production function with diminishing returns to labor, this increase in female labor force participation implies gains in income per capita of around $7 \%$.

Rising female participation rates due to fertility reductions may therefore have contributed significantly to the growth "miracles" in Asia and Ireland, which were in part driven by rising labor inputs (Bloom and Canning 2003; Bloom et al. 2000; Young 1995). Although labor supply per capita is bounded above, and so cannot affect the rate of economic growth in the very long run, it can give a substantial boost to growth over a reasonable period. If the transition from high fertility to low fertility is permanent, then there are long-run effects on female labor supply, and the gains in income per capita will also be permanent.

This paper is structured as follows: in Sect. 2, we present a simple model of labor supply and fertility and derive an equation for estimation. In Sect. 3, we describe the data we use, and in Sect. 4, we discuss abortion legislation as an instrument for fertility. In Sect. 5 we present the empirical results. We conclude with a summary and discussion.

\section{Model}

We propose a simple model of female fertility and labor supply choices. The utility function $U$ for a representative woman is defined over the household's consumption $c$, her leisure $d$, and fertility $n$. It is assumed to be given by:

$$
U(c, d, n)=\log \left(c-c_{0}\right)+\alpha \log (d)+\beta(1-m) n-k(N-n)
$$

For simplicity we assume utility is logarithmic in consumption and leisure and linear in the number of surviving children, $(1-m) n$, where $m$ is the infant mortality rate. The weight on consumption in utility is normalized to unity. The relative weight of leisure in utility is $\alpha>0$, while the relative weight given to surviving children is $\beta>0$. We can think of $c_{0}$ as 
representing subsistence consumption. In addition to the utility of children, we assume there is a cost, $k>0$, of avoiding childbirth and achieving fertility lower than $N$, the potential reproductive capacity (or fecundity rate), usually taken to be around 15 on average. Actual fertility can be regulated to be lower than this maximum. This regulation usually takes the form of delayed marriage, contraceptive use, abortion, or postpartum insusceptibility due to abstinence and breastfeeding after birth (Bongaarts 1978). Easier access to contraceptives and more lenient abortion legislation make fertility control easier and thus lower the cost of keeping fertility below its maximum level. A more realistic, but complex, approach would be to model the household's reproductive, contraceptive, and abortion choices explicitly; for simplicity we take the cost of fertility control as appearing directly in the utility function.

Total time available to a woman is normalized to one. This is divided between working time $l_{f}$, leisure time $d$, and child care. The time allocated to child care is assumed to be linear in the number of children, with a time cost per child of $b$. There are large differences in fertility and female labor force participation between the city and the countryside. This is due in part to the fact that in rural settings the family is both a consumption unit and production unit. Women in rural areas can combine "economic activity" with other tasks; childcare and work in the home can to some extent be carried out simultaneously. On the other hand, in urban areas the separation of home and workplace means that it is difficult to combine tasks, or switch quickly between tasks; for example there may be time costs of traveling to work. We allow for the possibility of a differential labor supply time requirement by adding a worktime-cost of $\phi u$ per unit of labor supplied, where $\phi>0$ and $u$ is an indicator of urbanization (though we could equivalently model rural work as having lower time costs because of the ability to multi-task at home). This gives us:

$$
1=(1+\phi u) l_{f}+d+b n(1-m)
$$

The additional time costs of working in towns and cities will tend to reduce the demand for children among urban women. They may also be other reasons for low demand for children in towns and cities, for example the high cost of housing space, and separation from the extended family who might provide assistance with child care, that we do not model here.

Consumption possibilities are limited by the amount of income the household earns. We assume that men and women cohabitate as a household unit, and the man earning a wage, $w_{m}$. The woman earns labor income given by the prevailing wage for women, $w_{f}$, multiplied by the amount of time she spends working $l_{f}$. All income earned is consumed, and the consumption constraint is defined as

$$
c=w_{f} l_{f}+w_{m}
$$

We assume $w_{m}+w_{f}>c_{0}$ so that consumption above the subsistence level is feasible. We treat the two constraints, (2) and (3), as binding; if they are regarded as inequality constraints the fact that consumption and leisure time are always desirable will make them binding under maximization. Given these time allocation and consumption constraints we can write utility as a function of labor supply and the number of children (leisure being the residual time from the time budget constraint):

$$
\begin{aligned}
V\left(n, l_{f}\right)= & \log \left(w_{f} l_{f}+w_{m}-c_{0}\right)+\alpha \log \left(1-(1+\phi u) l_{f}-b(1-m) n\right) \\
& +\beta(1-m) n-k(N-n)
\end{aligned}
$$


where $0 \leq n \leq N$ and $0 \leq l_{f} \leq 1$. The first-order conditions for an interior maximum with respect to $l$ and $n$ are:

$$
\begin{aligned}
& \frac{d V}{d l_{f}}=\frac{w_{f}}{w_{f} l_{f}+w_{m}-c_{0}}-\frac{\alpha(1+\phi u)}{1-(1+\phi u) l_{f}-b(1-m) n}=0 \\
& \frac{d V}{d n}=\frac{-\alpha b(1-m)}{1-(1+\phi u) l_{f}-b(1-m) n}+\beta(1-m)+k=0
\end{aligned}
$$

In Appendix 1, we show that the Hessian matrix of second derivatives is negative semidefinite, which implies that these first-order conditions do indeed generate a local maximum. Given a fixed number of children, $n$, the optimal labor supply is given by:

$$
l_{f}=\frac{1}{(1+\alpha)}\left(\alpha \frac{c_{0}}{w_{f}}-\alpha \frac{w_{m}}{w_{f}}+\frac{1-b(1-m) n}{1+\phi u}\right)
$$

while given a fixed labor supply $l_{f}$ the optimal number of children is:

$$
n=\frac{1}{b(1-m)}\left(1-(1+\phi u) l_{f}\right)-\frac{\alpha}{\beta(1-m)+k}
$$

We wish to estimate the structural Eq. 7 to find the effect of variations in fertility on female labor supply. However, fertility is endogenous, as is clear from Eq. 8. Both fertility and labor supply are jointly determined, and the parameters of Eq. 7 will not be identified in a simple ordinary least squares regression. The cost of fertility control, $\mathrm{k}$, will be positively correlated with the fertility decision through Eq. 8 but does not appear in the labor supply Eq. 7. Since the cost of fertility control affects labor supply only through its effect on the level of fertility, it can be used as an instrument for fertility in estimating Eq. 7.

While high fertility tends to lead to low labor supply, ceteris paribus, fertility and labor supply can rise together if the parameters in our model change. For example, a decrease in $\phi$, the time cost of labor in an urban setting, can increase both fertility and female labor supply, which is consistent with the positive correlation between female labor supply and fertility in OECD countries found by Engelhardt and Prskawetz (2004).

In order to derive an equation to estimate, we linearize Eq. 7 around the point $\left(\bar{n}, \bar{u}, \bar{m}, \bar{w}_{m}\right.$, $\bar{w}_{f}$ ) giving

$$
\begin{aligned}
l_{f}\left(n, u, m, w_{m}, w_{f}\right) \approx & l_{f}\left(\bar{n}, \bar{u}, \bar{m}, \bar{w}_{m}, \bar{w}_{f}\right)-\left[\frac{b(1-\bar{m})}{(1+\alpha)(1+\phi \bar{u})}\right] n \\
& -\left[\frac{\phi(1-b(1-\bar{m}) \bar{n})}{(1+\alpha)(1+\phi \bar{u})^{2}}\right] u+\left[\frac{b \bar{n}}{(1+\alpha)(1+\phi \bar{u})}\right] m \\
& -\left[\frac{\alpha}{(1+\alpha) \bar{w}_{f}}\right] w_{m}+\left[\frac{\alpha\left(\bar{w}_{m}-c_{0}\right)}{(1+\alpha)\left(\bar{w}_{f}\right)^{2}}\right] w_{f}
\end{aligned}
$$

We can average this linear equation over the population to give a relationship between average fertility and average female labor supply. The time costs of children imply that optimal female labor supply is decreasing in fertility. An urban setting should increase the time cost of working and reduce labor supply. We expect a high infant mortality rate to reduce the number of surviving children and increase labor supply. Male wages have only an income effect and should reduce female labor supply. As emphasized by Galor and Weil (1996) female wages relative to male wages play an important role in determining female labor market participation. The effect of female wages on labor supply depends on the balance of income and substitution effects. If $w_{m}>c_{0}$, the substitution effect dominates and conditional on fertility, labor supply is rising with female wages. On the other hand, if $w_{m}<c_{0}$ 
the income effect dominates, and with a given fertility, female labor supply is declining in the wage rate.

A difficulty emerges empirically in that we do not have comparable international data on male and female wages levels. To address this problem we assume a simple production function where output $Y$ depends on capital $K$ and aggregate effective labor $L$ :

$$
Y=K^{a} L^{1-a}, \quad \text { where } L=\left(L_{m} h_{m}+L_{f} h_{f}\right)
$$

with $0<a<1$. Effective labor is the sum of the male and female labor forces, $L_{m}$ and $L_{f}$, weighted by their education levels, $h_{m}$ and $h_{f}$, respectively. Taking wages of men, $w_{m}$ and women, $w_{f}$ to be their marginal products we have:

$$
w_{m}=(1-a)\left(\frac{K}{L}\right)^{a} h_{m}, \quad w_{f}=(1-a)\left(\frac{K}{L}\right)^{a} h_{f}
$$

Substituting into Eq. 9 and linearizing we can approximate the last two terms in Eq. 9 with

$$
\begin{aligned}
& -\left[\frac{\alpha}{(1+\alpha) \bar{w}_{f}}\right] w_{m}+\left[\frac{\alpha\left(\bar{w}_{m}-c_{0}\right)}{(1+\alpha)\left(\bar{w}_{f}\right)^{2}}\right] w_{f} \approx \\
& \quad\left[a(1-a)\left(\frac{\bar{K}}{\bar{L}}\right)^{1-a}\left(\frac{\alpha\left(\bar{w}_{m}-c_{0}\right)}{(1+\alpha)\left(\bar{w}_{f}\right)^{2}} \bar{h}_{f}-\frac{\alpha}{(1+\alpha) \bar{w}_{f}} \bar{h}_{m}\right)\right] \frac{K}{L} \\
& \quad-\left[\left(\frac{\alpha(1-a)}{(1+\alpha) \bar{w}_{f}}\right)\left(\frac{\bar{K}}{\bar{L}}\right)^{a}\right] h_{m}+\left[\left(\frac{\alpha\left(\bar{w}_{m}-c_{0}\right)(1-a)}{(1+\alpha)\left(\bar{w}_{f}\right)^{2}}\right)\left(\frac{\bar{K}}{\bar{L}}\right)^{a}\right] h_{f}
\end{aligned}
$$

Wages of both men and women rise with the capital-labor ratio. Male wages rise with male education levels while female wages rise with female education levels. Note that the coefficients on male and female education in this approach are the same sign as the original coefficients on male and female wages, so we expect female labor supply to fall with male education while the sign of the effect of female education depends on whether the income or substitution effect of higher wages dominates. It is problematic to include the capital to effective labor ratio, $K / L$, directly in the regression since the female labor force, and hence the total labor force, is endogenous. We proxy the effective capital labor ratio by $K / W$, the ratio of capital, $K$, to people of working age (ages 15-64) $W$.

The linearized equation we estimate is now

$$
l_{f}=\beta_{0}+\beta_{n} n+\beta_{u} u+\beta_{m} m+\beta_{k}(K / W)+\beta_{m} h_{m}+\beta_{f} h_{f}
$$

In our theory we take the view that female labor supply is a choice variable and represents a utility-maximizing decision. It may be that there are social restrictions on female work that limit choice. In such a case, a low level of female education may reflect lack of work opportunities as well as low female wages. We try to control for these unobserved cultural differences and social restrictions by adding fixed effects and time trends to the empirical analysis. However, it should be borne in mind that our estimates reflect the average effect of each variable on female labor supply across countries, and thus reflect the average over a set of heterogeneous settings where restrictions on female labor supply vary. 


\section{Data}

The data set we use in our empirical work is an unbalanced 5-year panel covering the period from 1960 to 2000 for 97 countries. $^{2}$ The dependent variable is female labor force participation. Labor force participation data are taken from the International Labour Organization (2007) and are based on national labor market surveys and censuses. The female participation rate is the number of economically active women divided by the total female population in the same age group. Although definitions vary slightly across countries, a woman is classified as "economically active" if she is either employed or actively looking for work (International Labor Organization 2007). We use data on the participation rate of women from five age groups: 20-24, 25-29, 30-34, 35-39, 40-44.

We are interested in the effect of the total fertility rate on female labor supply. The total fertility rate is taken from the World Development Indicators (World Bank 2006). The total fertility rate is the number of children a woman would be expected to have at the current age-specific fertility rates over her fertile years, usually taken to be $15-49$. We exclude the youngest age group 15-19 from the analysis since many of these young women are still in school. Fertility beyond age 44 is very low, so we exclude women aged 45 and over. Older women, who bore their children earlier in their fertile years, may still have children at home; their absence from the labor market during child rearing may make returning to work at later ages difficult. However, modeling these longer-term effects of fertility on labor supply at older ages requires a dynamic model where lagged fertility and lagged participation may matter. While this is possible (Bloom et al. 2007) we focus here on the contemporaneous effect of fertility on women who are currently of child bearing age.

Our other explanatory variables are: the percentage of the population living in urban areas; physical capital per working-age person; the infant mortality rate; and the average years of schooling of men and women. The percentage of population living in urban areas comes from World Development Indicators (World Bank 2006). The infant mortality rate is the number of deaths under 1 year of age per thousand births and is also taken from World Development Indicators. The physical capital stock is based on output and investment rates from Penn World Tables 6.2 (Heston et al. 2006), and is divided by the working-age population, taken from World Population Prospects (United Nations 2007). Our human capital measures are the average years of schooling in the female and male population aged 15 and older, respectively, as measured by Barro and Lee (2001).

Table 1 provides summary statistics for our main variables; a more detailed description of the data and data sources is provided in Appendix 2. The total fertility rate ranges from 1.18 (Spain and Italy in 1995) to 8.5 (Rwanda in 1980), with an average in the panel of 4.35. The average female labor force participation shows little variation across age groups within a country, but great variation across countries for each age group. Figure 1 plots average female participation rates in 2000 against real income per capita in the same year. These range from values close to $90 \%$ in Tanzania and Mozambique, to only 20\% in Egypt, to around 60 in the US, and display a slight U-shape.

\section{Abortion legislation as an instrument for fertility}

To construct an instrument for fertility we use information on national abortion legislation compiled by the United Nations (2002). The data contain detailed information on

$\overline{{ }^{2} \text { For a full list of countries, please see Table } 3 .}$ 
Table 1 Descriptive statistics

\begin{tabular}{|c|c|c|c|c|}
\hline Variable & Mean & SD & Min & Max \\
\hline Female labor force participation, age 20-24 & 55.82 & 18.47 & 12.24 & 100.00 \\
\hline Female labor force participation, age 25-29 & 55.76 & 19.88 & 10.88 & 100.00 \\
\hline Female labor force participation, age $30-34$ & 55.77 & 21.40 & 12.46 & 100.00 \\
\hline Female labor force participation, age 34-39 & 56.53 & 22.45 & 11.91 & 100.00 \\
\hline Female labor force participation, age $40-44$ & 56.52 & 22.73 & 11.70 & 100.00 \\
\hline Abortion: pregnancy life threatening & 0.95 & 0.21 & 0 & 1 \\
\hline Abortion: pregnancy threatening physical health & 0.56 & 0.50 & 0 & 1 \\
\hline Abortion: pregnancy threatening mental health & 0.52 & 0.50 & 0 & 1 \\
\hline Abortion: pregnancy consequent on rape & 0.37 & 0.48 & 0 & 1 \\
\hline Abortion: fetal impairment & 0.32 & 0.47 & 0 & 1 \\
\hline Abortion: economic reasons & 0.23 & 0.42 & 0 & 1 \\
\hline Abortion: on request & 0.17 & 0.38 & 0 & 1 \\
\hline Abortion index & 3.13 & 2.28 & 0 & 7 \\
\hline Average years of schooling, female age $>15$ years & 4.53 & 3.01 & 0.04 & 12.02 \\
\hline Average years of schooling, male age $>15$ years & 5.38 & 2.78 & 0.26 & 12.15 \\
\hline Capital per working-age person & 23.31 & 27.40 & 0.26 & 138.21 \\
\hline Infant mortality rate per 1000 & 63.79 & 51.88 & 2.90 & 285.00 \\
\hline Real GDP per capita (real 2004\$ PPP) & 7,354 & 7,547 & 171 & 64,640 \\
\hline Total fertility rate & 4.34 & 2.04 & 1.18 & 8.50 \\
\hline Urban population (\% of total) & 48.18 & 24.72 & 3.19 & 100.00 \\
\hline
\end{tabular}

Notes: Based on the sample of 766 observations

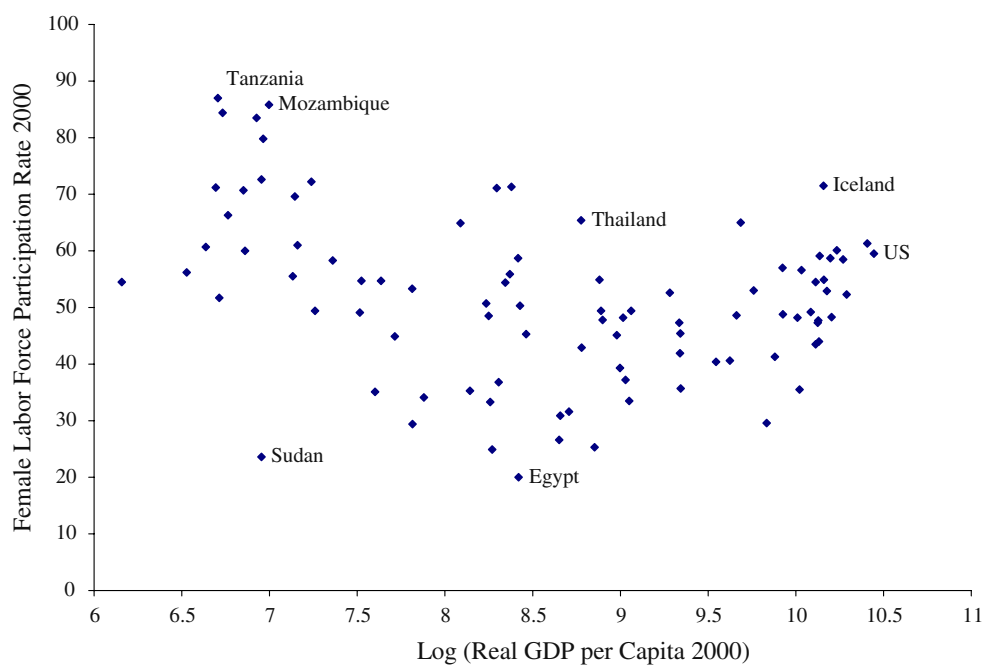

Fig. 1 Income per capita and female labor force participation, 2000. Source: income per capita is real income per capita (2004 PPP \$) from Penn World Tables. Labor force participation rates are from the International Labour Organization (2007) 
the legal availability of abortion over time. We use the United Nations' system to classify current laws. This system classifies seven legal reasons for an abortion: to save the life of the woman; to preserve her physical health; to preserve her mental health; consequent on rape or incest; fetal impairment; economic or social reasons; and available on request. Our data contain indicator variables for each of these seven categories. A " 1 " indicates that abortion is available for the given reason, and " 0 " means that it is not. When an abortion is available on request, we assume availability for any of the other reasons if this is not explicitly stated.

Although these categories are broad, they are not comprehensive descriptions of abortion law. There are frequently cutoffs for lawful abortions depending on the length of the pregnancy. The mechanisms for adjudicating if a pregnancy meets a particular criterion differ across countries, relying in some cases on a single doctor, while in others two or more doctors are required to agree. In some countries a husband's consent is required. The United Nations coding scheme ignores these additional factors and declares an abortion for a particular reason lawful if it is allowed at any time during the pregnancy. In federal systems, abortion laws sometimes differ across regions. In this case the law that covers the majority of the population, if one exists, is used to classify at the national level.

In many countries there is a divergence between law and practice, with abortions being widely available despite being technically illegal, or vice versa. We code according to the law in place rather than its enforcement and the practical availability of abortion. For example, in the United Kingdom abortion has been illegal since 1861 with an exception, introduced in 1929, to save the life of the mother. The Abortion Act of 1967 in the United Kingdom (excluding Northern Ireland) allows abortion to protect the life, physical and mental health of the mother, and in cases where there is a risk the child will be handicapped. The law also covers cases where a birth might affect the health of existing children and allows the woman's actual and potential environment to be taken into account. Legally, abortion is not explicitly available in the case of rape or simply on request. Although this is the legally restricted set of criteria, in practice the physical and mental health criteria appear to be interpreted liberally. They include the effects of childbirth on socio-economic circumstances and mental health so that de facto an abortion is available if a woman requests one and claims potential economic hardship or mental distress. In the case of rape a claim that abortion was needed to preserve the mental and physical health, and indeed the life, of the mother would be very likely to succeed (as in the case of Rex v. Bourne, 1938). We code Britain as allowing abortion only to save the life of the mother from 1960 to 1966 with the addition of legal abortion for the mother's physical and metal health, fetal impairment, and socio-economic reasons starting in 1967. We code that abortion is not allowed in cases of rape, or on request; though in practice claims for abortions on these grounds may well be accepted, in principle they still need to fall under one of the other legal categories.

A second example is Chile. The law of 1874 prohibited abortions carried out with malice; it was understood that abortions to save the life of the mother were permitted. This was explicitly recognized in the law of 1967 . The law was changed in 1989 to outlaw abortions in all circumstances. Despite these strict laws, abortion has been relatively common in Chile throughout the period (Singh and Wulf 1996). We code Chile as allowing abortion to save the life of the mother from 1960 to 1988 and as not allowing abortion under any circumstances thereafter.

Table 1 summarizes the abortion data. The "life threatening" indicator has an average of 0.95, which implies that almost all countries across the sample period allow abortion under this circumstance. There is more variation across countries and time for the availability of abortion on the remaining categories. We construct an index summarizing the availability of abortion. A country gets a score of zero if abortion is not legal for any reason. One is added to the score for each circumstance in which abortion is available, with a maximum score of 7. 
Table 2 Correlation between abortion laws

\begin{tabular}{|c|c|c|c|c|c|c|c|c|}
\hline & $\begin{array}{l}\text { Life } \\
\text { threatening }\end{array}$ & $\begin{array}{l}\text { Mother's } \\
\text { physical } \\
\text { health }\end{array}$ & $\begin{array}{l}\text { Mother's } \\
\text { mental } \\
\text { health }\end{array}$ & Rape & $\begin{array}{l}\text { Fetal } \\
\text { impairment }\end{array}$ & $\begin{array}{l}\text { Economic } \\
\text { reasons }\end{array}$ & Request & $\begin{array}{l}\text { Abortion } \\
\text { index }\end{array}$ \\
\hline Life threatening & 1.000 & & & & & & & \\
\hline Physical health & 0.238 & 1.000 & & & & & & \\
\hline Mental health & 0.221 & 0.932 & 1.000 & & & & & \\
\hline Rape & 0.165 & 0.616 & 0.587 & 1.000 & & & & \\
\hline Fetal impairment & 0.157 & 0.633 & 0.629 & 0.836 & 1.000 & & & \\
\hline Economic reasons & 0.135 & 0.542 & 0.578 & 0.745 & 0.813 & 1.000 & & \\
\hline Request & 0.120 & 0.505 & 0.542 & 0.715 & 0.754 & 0.875 & 1.000 & \\
\hline Abortion index & 0.273 & 0.828 & 0.834 & 0.870 & 0.900 & 0.873 & 0.839 & 1.000 \\
\hline $\begin{array}{l}\text { First principal } \\
\text { component }\end{array}$ & 0.253 & 0.815 & 0.822 & 0.874 & 0.906 & 0.883 & 0.850 & 0.997 \\
\hline $\begin{array}{l}\text { First principal } \\
\text { component } \\
\text { weight }\end{array}$ & 0.136 & 0.399 & 0.395 & 0.402 & 0.430 & 0.410 & 0.389 & \\
\hline
\end{tabular}

Although we found these abortion indicators to have significant explanatory power as a group, it is difficult to find independent effects for the different indicators. Table 2 shows the correlation matrix for the abortion variables. Apart from abortion when the pregnancy threatens the life of the mother, which is almost universally allowed, the other indicators are highly collinear. We find that each abortion variable has significant explanatory power for fertility when used singularly, but additional abortion variables add little to the fit of the first-stage regression. Using multiple instruments would have the potential advantage of allowing an over-identifying restrictions test of instrument validity; when we use multiple instruments we indeed pass this test. However, this test relies on at least one instrument being valid and lacks appeal in our context when the intuitive justification for each instrument is the same, and it is likely that either all, or none, of our instruments are valid. These issues are discussed in more detail in Murray (2006), and lead us to use only one instrument in our analysis. Rather than using one of the raw abortion measures we use an abortion index giving equal weight to each measure in an aggregate; this index has a slightly higher predictive power for fertility than any single abortion measure.

As an alternative to using a simple additive index, one might consider using the principal component of the seven abortion variables in the empirical analysis. As can be seen in Table 2, the first principal component is virtually identical to the index we use in our empirical specification. The correlation between the abortion index and the first principal component is 0.997. The weight assigned to each of the abortion indicators in the construction of the first principal component, shown on the final row of Table 2, is almost identical for each measure (except for the "life threatening" category), making it very similar to an additive index. For ease of interpretation, we use the abortion index rather than the first principal component.

As we shall see, our abortion index is correlated with fertility. Abortion is a common method of ending pregnancy worldwide (Henshaw et al. 1999) in developing countries as well as developed countries (Anarfi 2003).

A key issue is that for abortion legislation to be a valid instrument it must be uncorrelated with the error term in the female labor force participation regression. There are two ways instrument validity may break down. The first is if abortion laws affect female labor supply 
directly, and not via their effect on fertility. This seems unlikely. A more worrying issue is that abortion legislation is endogenous and responding to social factors that also influence fertility and female labor force participation.

The fact that laws and policies are endogenous, and not random treatments, makes it difficult to assess their effects. However, there are ways to address this problem. Romer and Romer $(1989,1994)$ argue that while monetary policy is endogenous, the willingness of the Federal Reserve to deliberately aim to generate a fall in output in order to reduce inflation, and the inflation threshold that produces this response, is not fixed and mechanical but the result of the personalities involved and the deliberative process. Such episodes therefore can be considered as random policy shocks whose effects can be used to make inferences on the impact of monetary policy. We argue that changes in abortion laws have similar characteristics.

Polices in a democratic, two-party system will tend to reflect the views of the median voter. If the distribution of voter preferences is uni-modal, changes in social and political forces that change the views of the median voter will tend to be reflected in government laws and regulations if these can be varied along a continuum. Abortion laws by their nature tend to vary discretely, by jumps, even if the underlying distribution of preferences varies smoothly.

Even if we think of abortion laws as lying on a continuum, legislation may still jump discreetly since the distribution of preferences on abortion tends to be bi-modal, with two clusters of people with extreme views. In such a model, change based on majority voting is discontinuous and occurs when one group enlarges above $50 \%$ of the population, even if the underlying distribution of voter preferences changes smoothly. In addition, legislators are elected based on voter preferences on many dimensions. When the distribution of preferences is close to $50 \%$ on each side of a bi-modal issue, the political cost to any abortion policy is roughly similar; legislators will be elected on other characteristics and may vote on abortion issues in a way that reflects their own preferences rather than those of their constituents (Medoff et al. 1995). This can make the passage of abortion laws contingent on the personal preferences of legislators elected based on other characteristics.

Table 3 gives the value of our abortion index for each country in our sample at the start of each decade (our complete data set is annual). Examination of changes in abortion laws in our data set shows many examples where the passage of the law at a particular time depended on elements that appear random. In the United Kingdom in the 1960s neither major political party proposed changes to the abortion law. Each year, however, a small number of laws are proposed by individual members of Parliament, selected by a random draw. David Steel won the right to present legislation in 1967 and his proposed abortion legislation was enacted. Abortion laws in many Commonwealth countries were based on United Kingdom law at the time they gained independence. These countries were influenced by the British legislation and in many cases introduced abortion legislation soon afterwards, often using parts of the British law as a basis for their own text (Peel et al. 1977).

In the United States many states had very restrictive abortions laws until 1973 when the Supreme Court's Roe v. Wade decision held that abortion was a fundamental right protected by the constitution. This right, however, is not explicit in the constitution and is based on an inferred right to privacy that some justices dissented from. Changing views of members of the court, or their replacement upon death or retirement, may change this decision. A majority opinion denying a fundament constitutional right to abortion was written for the case of Planned Parenthood v. Casey in 1992 but was changed when one of the five justices defected from the majority (Greenhouse 2005), though the ruling that was agreed upon did allow for government regulation of abortion. It appears that any future legal changes to abortion laws in United States will depend on the opinions of the nine justices of the Supreme Court, or their replacements; the timing of such changes may not be directly reflective of public opinion. 
Table 3 Abortion index scores

\begin{tabular}{|c|c|c|c|c|c|}
\hline Country & 1960 & 1970 & 1980 & 1990 & 2000 \\
\hline Afghanistan & & & 1 & & \\
\hline Algeria & 2 & 3 & 3 & 3 & 3 \\
\hline Argentina & & & & 2 & 4 \\
\hline Australia & 2 & 7 & 7 & 7 & 7 \\
\hline Austria & & & 7 & 7 & 7 \\
\hline Bahrain & & & 7 & 7 & 7 \\
\hline Bangladesh & & & 3 & 3 & 3 \\
\hline Barbados & 3 & 3 & 3 & 6 & 6 \\
\hline Belgium & 1 & 1 & 1 & 7 & 7 \\
\hline Benin & & 1 & 1 & 1 & 1 \\
\hline Botswana & & 1 & 1 & 1 & 5 \\
\hline Brazil & 2 & 2 & 2 & 2 & 2 \\
\hline Cameroon & 4 & 4 & 4 & 4 & 4 \\
\hline Canada & 1 & 7 & 7 & 7 & 7 \\
\hline Central African Republic & & 1 & 1 & 1 & 1 \\
\hline Chile & 1 & 1 & 1 & 0 & 0 \\
\hline China & & & 7 & 7 & 7 \\
\hline Colombia & & & 1 & 1 & \\
\hline Congo, Rep. & & & & 1 & 1 \\
\hline Costa Rica & & & 3 & 3 & 3 \\
\hline Cyprus & & 3 & 5 & 5 & 5 \\
\hline Denmark & 6 & 6 & 7 & 7 & 7 \\
\hline Dominican Republic & 1 & 1 & 1 & 1 & 1 \\
\hline Ecuador & & & 4 & 4 & 4 \\
\hline Egypt, Arab Rep. & & & 1 & 1 & 1 \\
\hline El Salvador & 0 & 0 & 0 & 0 & 0 \\
\hline Fiji & & & 4 & 4 & 4 \\
\hline Finland & & & 6 & 6 & 6 \\
\hline France & 1 & 1 & 7 & 7 & 7 \\
\hline Gambia, The & & & 3 & 3 & 3 \\
\hline Ghana & 0 & 0 & 0 & 5 & 5 \\
\hline Greece & 3 & 3 & 6 & 7 & 7 \\
\hline Guatemala & 0 & 0 & 1 & 1 & 1 \\
\hline Guinea-Bissau & & & 1 & 1 & 1 \\
\hline Haiti & & 4 & 4 & 4 & 4 \\
\hline Honduras & 1 & 1 & 1 & 1 & 1 \\
\hline Hungary & & 7 & 7 & 7 & 7 \\
\hline Iceland & & & 7 & 7 & 7 \\
\hline India & 1 & 1 & 6 & 6 & 6 \\
\hline Indonesia & 0 & 0 & 0 & 0 & 1 \\
\hline Iran, Islamic Rep. & 1 & 1 & 1 & 1 & 1 \\
\hline Iraq & & 2 & 2 & 2 & \\
\hline
\end{tabular}


Table 3 continued

\begin{tabular}{|c|c|c|c|c|c|}
\hline Country & 1960 & 1970 & 1980 & 1990 & 2000 \\
\hline Ireland & 1 & 1 & 1 & 1 & 1 \\
\hline Israel & 3 & 3 & 5 & 5 & 5 \\
\hline Italy & 1 & 1 & 7 & 7 & 7 \\
\hline Jamaica & 3 & 3 & 3 & 3 & 3 \\
\hline Japan & 7 & 7 & 7 & 7 & 7 \\
\hline Jordan & 0 & 0 & 3 & 3 & 3 \\
\hline Kenya & 3 & 3 & 3 & 3 & 3 \\
\hline Korea, Rep. & 0 & 0 & 7 & 7 & 7 \\
\hline Kuwait & & 1 & 4 & 4 & 4 \\
\hline Lesotho & 0 & 0 & 1 & 1 & 1 \\
\hline Liberia & & & 5 & 5 & 5 \\
\hline Malawi & 1 & 1 & 1 & 1 & 1 \\
\hline Malaysia & 1 & 1 & 1 & 3 & 3 \\
\hline Mali & 1 & 1 & 1 & 1 & 1 \\
\hline Mauritius & 1 & 1 & 1 & 1 & 1 \\
\hline Mexico & 2 & 2 & 2 & 4 & 4 \\
\hline Mozambique & 1 & 1 & 1 & 4 & 4 \\
\hline Nepal & & & 1 & 1 & 1 \\
\hline Netherlands & 1 & 1 & 7 & 7 & 7 \\
\hline New Zealand & 3 & 3 & 5 & 5 & 5 \\
\hline Nicaragua & 1 & 1 & 1 & 1 & 1 \\
\hline Niger & 1 & 1 & 1 & 1 & 1 \\
\hline Norway & & 3 & 7 & 7 & 7 \\
\hline Pakistan & 1 & 1 & 1 & 3 & 3 \\
\hline Panama & 1 & 1 & 1 & 3 & 3 \\
\hline Papua New Guinea & & 1 & 3 & 3 & 3 \\
\hline Peru & 3 & 3 & 3 & 3 & 3 \\
\hline Philippines & 1 & 1 & 1 & 1 & 1 \\
\hline Poland & & 6 & 6 & 6 & 4 \\
\hline Portugal & 1 & 1 & 1 & 5 & 5 \\
\hline Rwanda & & 1 & 3 & 3 & 3 \\
\hline Senegal & 1 & 1 & 1 & 1 & 1 \\
\hline Sierra Leone & & 3 & 3 & 3 & 3 \\
\hline Singapore & 1 & 7 & 7 & 7 & 7 \\
\hline South Africa & & & 5 & 5 & 7 \\
\hline Spain & 1 & 1 & 1 & 5 & 5 \\
\hline Sri Lanka & 1 & 1 & 1 & 1 & 1 \\
\hline Sudan & & 1 & 1 & 2 & 2 \\
\hline Swaziland & & 1 & 1 & 1 & 1 \\
\hline Sweden & 3 & 3 & 7 & 7 & 7 \\
\hline Switzerland & 3 & 3 & 3 & 3 & 3 \\
\hline Syrian Arab Republic & 1 & 1 & 1 & 1 & 1 \\
\hline
\end{tabular}


Table 3 continued

\begin{tabular}{|c|c|c|c|c|c|}
\hline Country & 1960 & 1970 & 1980 & 1990 & 2000 \\
\hline Tanzania & 3 & 3 & 3 & 3 & 3 \\
\hline Thailand & 4 & 4 & 4 & 4 & 4 \\
\hline Togo & 5 & 5 & 5 & 5 & 5 \\
\hline Trinidad and Tobago & 3 & 3 & 3 & 3 & \\
\hline Tunisia & & 1 & 7 & 7 & 7 \\
\hline Turkey & 5 & 5 & 5 & 7 & 7 \\
\hline Uganda & 3 & 3 & 3 & 3 & 3 \\
\hline United Kingdom & 1 & 5 & 5 & 5 & 5 \\
\hline United States & 2 & 2 & 7 & 7 & 7 \\
\hline Uruguay & 4 & 4 & 4 & 4 & 4 \\
\hline Venezuela, RB & 1 & 1 & 1 & 1 & 1 \\
\hline Zambia & & & 5 & 5 & 5 \\
\hline Zimbabwe & 1 & 1 & 4 & 4 & 4 \\
\hline Global average & 1.8 & 2.17 & 3.08 & 3.67 & 3.68 \\
\hline
\end{tabular}

Note: The global average is the average of the abortion index over countries that have complete data for 5 years listed here

While these considerations make the precise timing of changes to abortion laws random, the overall level of the law may reflect social forces. Besley and Case (2000) advocate using fixed effects in this case to control for differences between countries in these social factors. In addition, the trend in abortion laws may follow public opinion in the long run; to allow for this we also check the robustness of our result with respect to including country-specific time trends. It follows that in this case we identify the effect from abortion legislation that deviates from the average level and trend of social forces in that country. Although the level and time trend in abortion legislation may be endogenous, we take the exact timing of abortion legislation that generates deviations from these long-term trends to be random.

An alternative potential instrument in this context could be the measure of family planning program effort compiled by Ross and Stover (2001). The family planning effort score provides an aggregate of 30 components that reflect a government's commitment to family planning. We find that there is a positive correlation between these effort scores and our abortion law index. We do not use the effort scores as an instrument because of some of the components that are measured in the score reflect contraceptive use and may be highly responsive to fertility decisions and the demand for family planning (Kelly and Cutright 1983).

A final point about our instrument is that we treat the estimates as identifying a single effect of fertility on female labor force participation. If there is heterogeneity in the response across women, and abortion legislation only affects the fertility of a specific subgroup of the population, it is the average labor market response to fertility within this subgroup that we measure, not the population average response (Imbens and Angrist 1994).

\section{Results}

Our empirical approach is to estimate the female labor force participation rate of age group $a$ in a panel of countries indexed by $i$ at year $t$. We begin by estimating the equation 
Table 4 Determinants of female participation rates estimation: fixed effects

\begin{tabular}{|c|c|c|c|c|c|}
\hline & \multicolumn{5}{|c|}{ Dependent variable: female labor force participation, by age group } \\
\hline & $20-24$ & $25-29$ & $30-34$ & $35-39$ & $40-44$ \\
\hline Fertility (TFR) & $\begin{array}{l}-3.042 * * * \\
(0.61)\end{array}$ & $\begin{array}{l}-3.754 * * * \\
(0.64)\end{array}$ & $\begin{array}{l}-3.205 * * * \\
(0.69)\end{array}$ & $\begin{array}{l}-2.547 * * * \\
(0.72)\end{array}$ & $\begin{array}{l}-2.244 * * * \\
(0.69)\end{array}$ \\
\hline $\begin{array}{l}\text { Urban (\% of } \\
\text { population urban) }\end{array}$ & $\begin{array}{l}-0.0511 \\
(0.095)\end{array}$ & $\begin{array}{l}-0.290 * * * \\
(0.085)\end{array}$ & $\begin{array}{l}-0.327 * * * \\
(0.094)\end{array}$ & $\begin{array}{l}-0.320 * * * \\
(0.10)\end{array}$ & $\begin{array}{l}-0.234^{* *} \\
(0.092)\end{array}$ \\
\hline $\begin{array}{l}\text { Capital } \\
\text { stock/working age } \\
\text { population }\end{array}$ & $\begin{array}{l}0.134 * * * \\
(0.035)\end{array}$ & $\begin{array}{l}0.406^{* * * *} \\
(0.043)\end{array}$ & $\begin{array}{l}0.360 * * * \\
(0.057)\end{array}$ & $\begin{array}{l}0.338 * * * \\
(0.059)\end{array}$ & $\begin{array}{l}0.320 * * * \\
(0.054)\end{array}$ \\
\hline Infant mortality rate & $\begin{array}{l}0.0171 \\
(0.025)\end{array}$ & $\begin{array}{l}0.0913 * * * \\
(0.027)\end{array}$ & $\begin{array}{l}0.102 * * * \\
(0.029)\end{array}$ & $\begin{array}{l}0.0905 * * * \\
(0.032)\end{array}$ & $\begin{array}{l}0.115^{* * * *} \\
(0.030)\end{array}$ \\
\hline Male education & $\begin{array}{l}-1.245^{*} \\
(0.67)\end{array}$ & $\begin{array}{l}-1.200 * \\
(0.70)\end{array}$ & $\begin{array}{l}-1.443^{*} \\
(0.76)\end{array}$ & $\begin{array}{l}-1.180 \\
(0.83)\end{array}$ & $\begin{array}{l}-1.348^{*} \\
(0.79)\end{array}$ \\
\hline Female education & $\begin{array}{l}2.556^{* * * *} \\
(0.79)\end{array}$ & $\begin{array}{l}2.901 * * * \\
(0.89)\end{array}$ & $\begin{array}{l}3.217 * * * \\
(1.02)\end{array}$ & $\begin{array}{l}2.975 * * * \\
(1.07)\end{array}$ & $\begin{array}{l}2.663 * * * \\
(1.00)\end{array}$ \\
\hline$R$-squared & 0.91 & 0.91 & 0.91 & 0.91 & 0.92 \\
\hline
\end{tabular}

Notes: All specifications are based on a sample of 766 observations and include time dummies and country fixed effects. Robust standard errors in parentheses

* Significant at $10 \%$

** Significant at $5 \%$

$* * *$ Significant at $1 \%$

$$
\begin{aligned}
l_{f a i t}= & \beta_{a n} n_{i t}+\beta_{a u} u_{i t}+\beta_{a m} m_{i t}+\beta_{a k}(K / W)_{i t} \\
& +\beta_{a h_{m}} h_{m i t}+\beta_{a h_{f}} h_{f i t}+\sigma_{a i}+\tau_{a t}
\end{aligned}
$$

This is identical to Eq. 13 derived in the theory section except that we index age, country, and year, control for country fixed effects $\sigma_{a i}$ and world wide time dummies $\tau_{a t}$. The fixed effects capture differences across countries that are fixed over time while the time dummies capture unobserved worldwide changes. Note that each of the parameters, fixed effects and time dummies can vary by age group, $a$; The regression for the participation of each age group is run separately. The results are reported for five 5-year age groups: 20-24, 25-29, 30-34, 34-39, and 40-44. The results for this specification estimated by ordinary least squares (OLS), with fixed effects and time dummies, are summarized in Table 4 below.

Table 4 shows that the effect of fertility on female labor force participation is negative and statistically significant for all age groups between 20 and 44 . The estimated effect of urban share is negative; this effect implies high participation in rural economies even if fertility is high. Capital per working-age person, which is correlated with higher overall wages, appears to have a positive effect. As expected, the infant mortality rate has a positive effect. Male education appears to reduce female labor force participation, which is consistent with male earnings producing an income effect that lowers female work incentives, while female education appear to have a positive effect.

In Table 5, we estimate the same relationship with two-stage least squares, an instrumental variable (IV) estimator, using our abortion index as an instrument for fertility. The estimated fertility effects remain negative and significant. We report the first stage of the two-stage regression in Column 1 of Table 6. Our abortion index is statistically significant as a predictor of fertility. The maximum increase in the abortion index (from 0 to 7 ) leads to a predicted reduction in fertility of about 0.4 children. The instrument is sufficiently highly 
Table 5 Determinants of female participation rates estimation: IV with fixed effects

\begin{tabular}{|c|c|c|c|c|c|}
\hline & \multicolumn{5}{|c|}{ Dependent variable: female labor force participation, by age group } \\
\hline & $20-24$ & $25-29$ & $30-34$ & $35-39$ & $40-44$ \\
\hline Fertility $(\mathrm{TFR})^{\mathrm{a}}$ & $\begin{array}{l}-8.209 * * \\
(3.69)\end{array}$ & $\begin{array}{l}-15.93 * * * \\
(4.92)\end{array}$ & $\begin{array}{l}-17.57 * * * \\
(6.05)\end{array}$ & $\begin{array}{l}-15.17 * * \\
(5.99)\end{array}$ & $\begin{array}{l}-12.92 * * \\
(5.51)\end{array}$ \\
\hline $\begin{array}{l}\text { Urban (\% of } \\
\text { population urban) }\end{array}$ & $\begin{array}{l}-0.139 \\
(0.095)\end{array}$ & $\begin{array}{l}-0.498 * * * \\
(0.13)\end{array}$ & $\begin{array}{l}-0.572 * * * \\
(0.16)\end{array}$ & $\begin{array}{l}-0.535^{* * * *} \\
(0.16)\end{array}$ & $\begin{array}{l}-0.416^{* * * *} \\
(0.14)\end{array}$ \\
\hline $\begin{array}{l}\text { Capital } \\
\text { stock/working age } \\
\text { population }\end{array}$ & $\begin{array}{l}0.211 * * * \\
(0.066)\end{array}$ & $\begin{array}{l}0.587 * * * \\
(0.083)\end{array}$ & $\begin{array}{l}0.574 * * * \\
(0.10)\end{array}$ & $\begin{array}{l}0.526 * * * \\
(0.10)\end{array}$ & $\begin{array}{l}0.479 * * * \\
(0.097)\end{array}$ \\
\hline Infant mortality rate & $\begin{array}{l}0.0665 \\
(0.046)\end{array}$ & $\begin{array}{l}0.208 * * * \\
(0.064)\end{array}$ & $\begin{array}{l}0.239 * * * \\
(0.074)\end{array}$ & $\begin{array}{l}0.211 * * * \\
(0.073)\end{array}$ & $\begin{array}{l}0.217 * * * \\
(0.066)\end{array}$ \\
\hline Male education & $\begin{array}{l}-0.129 \\
(1.09)\end{array}$ & $1.430(1.49)$ & $\begin{array}{l}1.659 \\
(1.67)\end{array}$ & $\begin{array}{l}1.546 \\
(1.63)\end{array}$ & $\begin{array}{l}0.958 \\
(1.45)\end{array}$ \\
\hline Female education & $\begin{array}{l}-0.523 \\
(2.32)\end{array}$ & $\begin{array}{l}-4.356 \\
(3.12)\end{array}$ & $\begin{array}{l}-5.345 \\
(3.66)\end{array}$ & $\begin{array}{l}-4.547 \\
(3.58)\end{array}$ & $\begin{array}{l}-3.699 \\
(3.25)\end{array}$ \\
\hline$R$-squared & 0.90 & 0.84 & 0.82 & 0.85 & 0.88 \\
\hline
\end{tabular}

Notes: All specifications are based on a sample of 766 observations and include time dummies and country fixed effects

a Fertility (TFR) is instrumented using the abortion index. First-stage results are shown in Column 1 of Table 6.

Robust standard errors in parentheses

* Significant at $10 \%$

** Significant at $5 \%$

$* * *$ Significant at $1 \%$

correlated with fertility to avoid the weak instrument problem. A Cragg-Donald F-statistic of 11.76 exceeds the $5 \%$ critical value for a test of a relative bias of more than $10 \%$ in our second-stage estimates (Stock and Yogo 2005).

The point estimate of the effect of fertility on female labor supply from the instrumental variable estimation appears large in absolute magnitude relative to the OLS estimates presented in Table 4. If higher female labor supply depresses fertility, the OLS estimate should be too large, and the IV estimate should correct this. One possible explanation for an increased estimated effect when we instrument is that measurement error may attenuate the OLS estimates and instrumentation corrects this.

In the OLS estimates in Table 4, female education is associated with higher female labor market participation, while male education is associated with lower female participation. In Table 5, when fertility is instrumented, these education effects on female participation are not statistically significant. This may be linked to measurement error in the total fertility rate. If fertility is measured with error and education levels are strongly correlated with fertility, education may proxy for the "missing" fertility variable.

Note that education has strong effects on fertility in the first-stage regression reported in Column 1 of Table 6. Fertility falls as female education levels rise, but increases with male education levels. Because the effect of female education is larger, an equal rise in education for both sexes implies lower fertility. It follows that, conditional on fertility, education may not be significant in the participation equation, but it still has a large impact on female labor market participation through its effect on fertility. This is similar to the argument by Smith and Ward (1985) that the effect of higher female wages on female labor supply works to a large extent through reductions in fertility. 
Table 6 Determinants of fertility first-stage results

Notes: Robust standard errors in parentheses

\begin{tabular}{lll}
\hline & \multicolumn{2}{l}{ Dependent variable: total fertility rate } \\
\hline Abortion index & $-0.058^{* * *}$ & $-0.048^{* * *}$ \\
& $(0.017)$ & $(0.018)$ \\
Urban (\% of population & $-0.016^{* * *}$ & $-0.039 * * *$ \\
urban) & $(0.006)$ & $(0.008)$ \\
Capital stock/working age & $0.016^{* * *}$ & $0.036 * * *$ \\
population & $(0.0023)$ & $(0.006)$ \\
Infant mortality rate & $0.010^{* * *}$ & $-0.004 *$ \\
& $(0.002)$ & $(0.002)$ \\
Male education & $0.227 * * *$ & $0.269 * * *$ \\
& $(0.060)$ & $(0.067)$ \\
Female education & $-0.593 * * *$ & $-0.440 * * *$ \\
& $(0.061)$ & $(0.074)$ \\
Period fixed effects & Yes & Yes \\
Country fixed effects & Yes & Yes \\
Country specific time trends & No & Yes \\
Observations & 766 & 766 \\
$R$-squared & 0.96 & 0.99 \\
Cragg-Donald F-stat & 11.76 & 8.98 \\
\hline
\end{tabular}

The total effect of education on female labor supply, including its effect via fertility, can be seen in the reduced form regression reported in Table 7. This regression can be regarded as a linearized version of the equation for female labor supply derived from combining Eqs. 7 and 8 , eliminating fertility, and expressing female participation as a function of the exogenous variables alone. In this regression we replace fertility with the abortion index. Allowing for its indirect effect through fertility, each year of female education increases participation by between 4 and 5 percentage points.

Although we control for country fixed effects and time dummies in the empirical specifications presented in the previous section, one may still worry about country-specific trends that are not picked up by time fixed effects. Attitudes towards the role of women in society may change, affecting abortion legislation, fertility, and female labor force participation. In this case these variables may move together, reflecting deeper underlying forces, even without there being a direct causal link between them. Our time dummies pick up worldwide trends but these underlying cultural trends may vary by country. To check the robustness of our results to the presence of country-specific cultural change, we repeat the IV analysis reported in Table 5 with the addition of country-specific time trends. The equation we estimate is:

$$
\begin{aligned}
l_{\text {fait }}= & \beta_{a n} n_{i t}+\beta_{a u} u_{i t}+\beta_{a m} m_{i t}+\beta_{a k}(K / W)_{i t} \\
& +\beta_{a h_{m}} h_{m i t}+\beta_{a h_{f}} h_{f i t}+\sigma_{a i}+\tau_{a t}+\lambda_{a i} t
\end{aligned}
$$

Each age group, in each country, now has its own time trend. The results, which are presented in Table 8, confirm our previous findings. The inclusion of a country-specific time trend slightly lowers the estimated effect of fertility on female labor supply but it remains statistically significant at the 5\% level for women aged 30-44 and at the 10\% level for women between 20 and 29.

In this formulation the estimated effect of female education on female labor supply at older ages, at a given fertility level, is negative, though this effect is only statistically significant at the $10 \%$ level. We report the first stage of the regression in Table 8 in Column 2 of Table 6. 
Table 7 Determinants of female participation rates estimation: reduced form with fixed effects

\begin{tabular}{|c|c|c|c|c|c|}
\hline & \multicolumn{5}{|c|}{ Dependent variable: female labor force participation, by age group } \\
\hline & $20-24$ & $25-29$ & $30-34$ & $35-39$ & $40-44$ \\
\hline Abortion index & $\begin{array}{l}0.483 * \\
(0.256)\end{array}$ & $\begin{array}{l}0.937 * * * \\
(0.249)\end{array}$ & $\begin{array}{l}1.034 * * * \\
(0.270)\end{array}$ & $\begin{array}{l}0.892 * * * \\
(0.272)\end{array}$ & $\begin{array}{l}0.760 * * * \\
(0.254)\end{array}$ \\
\hline $\begin{array}{l}\text { Urban (\% of } \\
\text { population urban) }\end{array}$ & $\begin{array}{l}-0.004 \\
(0.097)\end{array}$ & $\begin{array}{l}-0.236^{* * * *} \\
(0.089)\end{array}$ & $\begin{array}{l}-0.283^{* * * *} \\
(0.097)\end{array}$ & $\begin{array}{l}-0.285 * * * \\
(0.103)\end{array}$ & $\begin{array}{l}-0.203^{* *} \\
(0.093)\end{array}$ \\
\hline $\begin{array}{l}\text { Capital } \\
\text { stock/working age } \\
\text { population }\end{array}$ & $\begin{array}{l}0.075 * * \\
(0.032)\end{array}$ & $\begin{array}{l}0.324 * * * \\
(0.041)\end{array}$ & $\begin{array}{l}0.284 * * * \\
(0.055)\end{array}$ & $\begin{array}{l}0.276^{* * * *} \\
(0.057)\end{array}$ & $\begin{array}{l}0.265 * * * \\
(0.051)\end{array}$ \\
\hline Infant mortality rate & $\begin{array}{l}-0.017 \\
(0.025)\end{array}$ & $\begin{array}{l}0.045^{*} \\
(0.026)\end{array}$ & $\begin{array}{l}0.060 * * \\
(0.028)\end{array}$ & $\begin{array}{l}0.057 * \\
(0.031)\end{array}$ & $\begin{array}{l}0.085 * * * \\
(0.029)\end{array}$ \\
\hline Male education & $\begin{array}{l}-1.995^{* * *} \\
(0.715)\end{array}$ & $\begin{array}{l}-2.191 * * * \\
(0.712)\end{array}$ & $\begin{array}{l}-2.334 * * * \\
(0.763)\end{array}$ & $\begin{array}{l}-1.901^{* *} \\
(0.817)\end{array}$ & $\begin{array}{l}-1.979^{* *} \\
(0.795)\end{array}$ \\
\hline Female education & $\begin{array}{l}4.342 * * * \\
(0.784)\end{array}$ & $\begin{array}{l}5.084 * * * \\
(0.819)\end{array}$ & $\begin{array}{l}5.068 * * * \\
(0.902)\end{array}$ & $\begin{array}{l}4.442 * * * \\
(0.928)\end{array}$ & $\begin{array}{l}3.957 * * * \\
(0.875)\end{array}$ \\
\hline$R$-squared & 0.908 & 0.907 & 0.903 & 0.906 & 0.917 \\
\hline
\end{tabular}

All regressions are based on 766 observations and include time and country fixed effects. Robust standard errors in parentheses

* Significant at $10 \%$

** Significant at $5 \%$

$* * *$ Significant at $1 \%$

Table 8 Determinants of female participation rates estimation: IV with fixed effects and country-specific time trends

\begin{tabular}{|c|c|c|c|c|c|}
\hline & \multicolumn{5}{|c|}{ Dependent variable: female labor force participation, by age group } \\
\hline & $20-24$ & $25-29$ & $30-34$ & $35-39$ & $40-44$ \\
\hline Fertility $(\mathrm{TFR})^{\mathrm{a}}$ & $\begin{array}{l}-6.221^{*} \\
(3.40)\end{array}$ & $\begin{array}{l}-5.239 * \\
(2.96)\end{array}$ & $\begin{array}{l}-8.096 * * \\
(3.48)\end{array}$ & $\begin{array}{l}-9.180 * * \\
(4.01)\end{array}$ & $\begin{array}{l}-8.739 * * \\
(4.28)\end{array}$ \\
\hline $\begin{array}{l}\text { Urban (\% of } \\
\text { population urban) }\end{array}$ & $\begin{array}{l}-0.131 \\
(0.15)\end{array}$ & $\begin{array}{l}-0.319 * * \\
(0.13)\end{array}$ & $\begin{array}{l}-0.304 * \\
(0.17)\end{array}$ & $\begin{array}{l}-0.363^{*} \\
(0.19)\end{array}$ & $\begin{array}{l}-0.365^{*} \\
(0.19)\end{array}$ \\
\hline $\begin{array}{l}\text { Capital } \\
\text { stock/working age } \\
\text { population }\end{array}$ & $\begin{array}{l}0.0243 \\
(0.14)\end{array}$ & $\begin{array}{l}0.238 * \\
(0.13)\end{array}$ & $\begin{array}{l}0.289 * * \\
(0.14)\end{array}$ & $\begin{array}{l}0.285^{*} \\
(0.16)\end{array}$ & $\begin{array}{l}0.322 * \\
(0.17)\end{array}$ \\
\hline Infant mortality rate & $\begin{array}{l}0.011 \\
(0.024)\end{array}$ & $\begin{array}{l}0.056 * * * \\
(0.022)\end{array}$ & $\begin{array}{l}0.030 \\
(0.025)\end{array}$ & $\begin{array}{l}-0.002 \\
(0.029)\end{array}$ & $\begin{array}{l}0.035 \\
(0.030)\end{array}$ \\
\hline Male education & $\begin{array}{l}0.858 \\
(1.02)\end{array}$ & $\begin{array}{l}0.192 \\
(0.87)\end{array}$ & $\begin{array}{l}1.186 \\
(1.02)\end{array}$ & $\begin{array}{l}1.655 \\
(1.23)\end{array}$ & $\begin{array}{l}1.857 \\
(1.29)\end{array}$ \\
\hline Female education & $\begin{array}{l}-1.941 \\
(1.58)\end{array}$ & $\begin{array}{l}-1.027 \\
(1.38)\end{array}$ & $\begin{array}{l}-2.831^{*} \\
(1.59)\end{array}$ & $\begin{array}{l}-3.435^{*} \\
(1.89)\end{array}$ & $\begin{array}{l}-3.844^{*} \\
(1.97)\end{array}$ \\
\hline$R$-squared & 0.98 & 0.98 & 0.98 & 0.98 & 0.98 \\
\hline
\end{tabular}

Notes: All specifications are based on a sample of 766 observations and include time dummies, country fixed effects and country-specific time trends. Robust standard errors in parentheses

${ }^{a}$ Fertility (TFR) is instrumented using the abortion index. First stage results are shown in Table 4

* Significant at $10 \%$

** Significant at $5 \%$

*** Significant at $1 \%$ 
Again we see that female education has a negative effect on fertility and will thus increase female labor supply. The Cragg-Donald test statistic again rejects the hypothesis that our instrument is weak at the $5 \%$ level.

We now turn to the issue of the size of the estimated effect; we try to put the magnitude of the effect in context. Averaging the coefficients on fertility reported in Table 8, our estimates imply a reduction in labor supply of 7.5 percentage points during the fertile years for each child born. Summing over the 25 years from ages 20 to 44, this translates to a loss of 1.9 years of work for each child born. Fertility in our sample ranges from 8.5 to 1.2. During the fertility transition reductions in total fertility rates of four children (e.g. from 6.5 to 2.5 births per woman) are common. Such a reduction in fertility implies an increase in female labor supply during the fertile years by about 8 years, close to $18 \%$ of a woman's normal working life of 45 years (age 20-65, say).

From Table 1, we see that on average female labor force participation rates are around $50 \%$. Assuming all men work, and men and women have equal population numbers, we can derive that total labor supply will rise by about $11 \%$ due to increased female labor market participation when fertility declines by four births per woman. If capital increases in line with the rise in labor supply, and we have constant returns to scale, income will also rise by $11 \%$. If we have a Cobb-Douglas production function with diminishing returns to labor as in Eq. 10, the effect on income depends on the coefficient on labor, $1-\alpha$. If the wage equals the marginal product of labor, as it should with competitive markets, $1-\alpha$ is the share of labor income in total income- this is about $2 / 3$ in most countries. Given this figure for $1-\alpha$, an $11 \%$ increase in labor supply will raise income (and income per capita) by about $7 \%$.

Our approach may underestimate the total effect of fertility decline on female labor supply. Fertility may also affect the labor supply of older women as they may have to care for children born earlier but who have not yet left home. There may be persistence in labor supply, so that women who do not participate when young because of their children, do not re-enter the market when they are older. Estimating the effect of fertility on older women, who have completed their fertility, however requires a dynamic model where lagged fertility and labor force participation matters.

\section{Discussion and conclusion}

The concept of the "demographic dividend" (Bloom et al. 2003) elucidates the economic benefits that a country can gain if it experiences a decline in fertility. The decline in fertility increases the ratio of working-age to total population, increasing income per capita. Declines in fertility can also increase physical and human capital per capita (Galor and Weil 1999, 2000). We argue here that, in addition, there is the positive behavioral response of female labor force participation, which further increases labor supply per capita and income per capita.

In this paper, we have only considered the effect of fertility on female labor supply. The model does not account for the possible effect on education of a decline in fertility. Increased female labor supply may raise the economic returns to women's schooling, providing positive incentives for women to invest in education. The effect of fertility on saving, which is also important, is not taken into account. To the extent that children provide old-age support to their parents, a decline in fertility may spur savings for old age and retirement. The decline in fertility may also have beneficial effects though allowing greater investment in child health and education as predicted by the quantity-quality tradeoff models 
(Becker and Tomes 1976; Becker 1965). These mechanisms suggest that the overall effect of a fertility decline on income levels may be even larger than we report.

Acknowledgements The authors are grateful to David Weil and the participants in the Workshop on Population Aging and Economic Growth for their valuable comments. We extend our thanks to Mansour Farahani for compiling the family planning data. Support for this research was provided by grant number 5P30AG024409 from the National Institute on Aging, National Institutes of Health, and by grants from the William and Flora Hewlett Foundation and the John D. and Catherine T. MacArthur Foundation.

\section{Appendix 1}

We have

$$
\begin{aligned}
\frac{\partial^{2} V}{\partial n^{2}} & =\frac{-\alpha b^{2}(1-m)^{2}}{\left(1-(1+\phi u) l_{f}-b(1-m) n\right)^{2}}<0 \\
\frac{\partial^{2} V}{\partial l_{f}^{2}} & =-\frac{w_{f}^{2}}{\left(w_{m}+w_{f} l_{f}+c_{0}\right)^{2}}-\frac{\alpha(1+\phi u)^{2}}{\left(1-(1+\phi u) l_{f}-b(1-m) n\right)^{2}}<0 \\
\frac{d^{2} V}{d l_{f}^{2}} \frac{d^{2} V}{d n^{2}}-\left(\frac{d^{2} V}{d n d l_{f}}\right)^{2} & =\frac{\alpha b^{2}(1-m)^{2}}{\left(1-(1+\phi u) l_{f}-b(1-m) n\right)^{2}}\left[\frac{w_{f}^{2}}{\left(w_{m}+w_{f} l_{f}+c_{0}\right)^{2}}\right]>0 .
\end{aligned}
$$

Hence the Hessian matrix of 2nd derivatives is negative semi-definite and the first-order conditions give a local maximum.

\section{Appendix 2}

See Table 9.

Table 9 Variable descriptions

\footnotetext{
Age-group-specific female labor force participation
}

Fertility (TFR)

Urban population
The labor force participation rate is the number of women in the labor force in a given age group divided by the female population of the same age group. Labor force participation data are from the International Labour Organization (1997, 2007). The data from 1960-1980 and from 1980-2000 are taken from two different data sets. To ensure continuity in the data we link the two data sets by multiplying the 1960-80 data by a proportionality factor to agree with the 1980 figures from the 1980-2000 dataset. The changes this induces are very small

The total fertility rate is the average number of children that would be born to a woman over her fertile life if she were to experience the current age-specific fertility rate through these years. The data are taken from the World Development Indicators (World Bank 2006). For the missing survey years 1965 and 1975, we take the linear averages of 1962 and 1967, and 1972 and 1977 survey values, respectively

Percent of the total population living in an urban area. Source: World Development Indicators (World Bank 2006) 
Table 9 continued

Capital per working-age population
Total capital stock in 2004 US\$ PPP from the Penn World Tables 6.2

(Heston et al. 2006) divided by the population in the age groups 15-64. Population data come from the World Population Prospects (United Nations 2007). The capital stock series for each country is computed by a perpetual inventory method. We initialize the capital series in the first year for which there is investment data in the Penn World Tables, setting it equal to the average investment/GDP ratio in the first 5 years of data, multiplied by the level of GDP in the initializing period, and divided by .07 , our assumed depreciation rate. This is the capital stock we would expect in the initial year if the investment/GDP ratio we use is representative of previous rates. Each succeeding period's capital is given by current capital minus depreciation at $7 \%$, plus the level of current investment

Infant mortality rate

Mortality before age 1 year per 1000 births. Source: World Development Indicators (World Bank 2006)

Average years of schooling in the female/male population $>15$

Abortion index
The average years of schooling among females/males above the age of 15 . Source: Barro and Lee (2001)

Abortion index is the sum of the 7 abortion law indicator variables. In each abortion law category - life threatening, physical health of the mother, mental health of the mother, rape, fetal impairment, economic reasons, and on request - a one indicates that an abortion is legally available for the classified reason and a zero that it is not. The Abortion Index ranges from zero, which indicates that abortion is not legal under any classification, and seven, which means that an abortion is available for all of the seven reasons. Data Source: United Nations (2002)

\section{References}

Anarfi, J. (2003). The role of local herbs in the recent fertility decline in Ghana: Contraceptives or abortifacients? In J. M. Magone \& A. M. Basu (Eds.), The sociocultural and political aspects of abortion: Global perspectives. Westport: Greenwood Publishing Group.

Angrist, J., \& Evans, W. (1998). Children and their parents' labor supply: Evidence from exogenous variation in family size. The American Economic Review, 88(3), 450-477.

Angrist, J. D., \& Evans, W. N. (1996). Schooling and labor market consequences of the 1970 state abortion reforms. NBER Working Paper W5406.

Bailey, M. J. (2006). More power to the pill: The impact of contraceptive freedom on women's lifecycle labor supply. The Quarterly Journal of Economics, 121(1), 289-320.

Barro, R. J., \& Lee, J. W. (2001). International data on education attainment: Updates and implications. Oxford Economic Papers, 53(3), 541-563. doi:10.1093/oep/53.3.541.

Becker, G., \& Tomes, N. (1976). Child endowments and the quantity and quality of children. The Journal of Political Economy, 84(4), 143-162. doi:10.1086/260536.

Becker, G. S. (1965). A theory of the allocation of time. The Economic Journal, 75, 493-517. doi:10.2307/ 2228949.

Becker, G. S., Glaeser, E. L., \& Murphy, K. M. (1999). Population and economic growth. The American Economic Review, 89(2), 145-149.

Besley, T., \& Case, A. (2000). Unnatural experiments? Estimating the incidence of endogenous policies. The Economic Journal, 110(467), 672-694. doi:10.1111/1468-0297.00578.

Bloom, D. E., \& Canning, D. (2003). Contraception and the Celtic Tiger. The Economic and Social Review, 34(3), 229-247.

Bloom, D. E., Canning, D., Fink, G., \& Finlay, J. E. (2007). Fertility, female labor force participation, and the demographic dividend. NBER Working Paper, 13583.

Bloom, D. E., Canning, D., \& Graham, B. (2003). Longevity and life cycle savings. The Scandinavian Journal of Economics, 105(3), 319-338. doi:10.1111/1467-9442.t01-1-00001.

Bloom, D. E., Canning, D., \& Malaney, P. (2000). Demographic change and economic growth in Asia. Population and Development Review, 26, 257-290. 
Bloom, D. E., Canning, D., Mansfield, R., \& Moore, M. (2007). Demographic change, social security systems, and savings. Journal of Monetary Economics, 54(1), 92-114. doi:10.1016/j.jmoneco.2006.12.004.

Bloom, D. E., Canning, D., \& Sevilla, J. (2003). The demographic dividend: A new perspective on the economic consequences of population change. Population Matters Monograph MR-1274, RAND, Santa Monica.

Bloom, D. E., \& Freeman, R. B. (1986). The effects of rapid population growth on labor supply and employment in developing countries. Population and Development Review, 12(3), 381-414. doi:10.2307/1973216.

Bloom, D. E., \& Williamson, J. G. (1998). Demographic transitions and economic miracles in emerging Asia. The World Bank Economic Review, 12(3), 419-455.

Bongaarts, J. (1978). A framework for analyzing the proximate determinants of fertility. Population and Development Review, 4(1), 105-132. doi:10.2307/1972149.

Brander, J. A., \& Dowrick, S. (1994). The role of fertility and population in economic growth. Journal of Population Economics, 7(1), 1-25. doi:10.1007/BF00160435.

Browning, M. (1992). Children and household economic behavior. Journal of Economic Literature, 30(3), 1434-1475.

Canning, D. (1988). Increasing returns to scale in industry and the role of agriculture in growth. Oxford Economic Papers, 40(3), 463-476.

Engelhardt, H., \& Prskawetz, A. (2004). On the changing correlation between fertility and female employment over space and time. European Journal of Population, 20(1), 35-62. doi:10.1023/B:EUJP.0000014543. $95571.3 \mathrm{~b}$.

Galor, O. (2005). The demographic transition and the emergence of sustained economic growth. Journal of the European Economic Association, 3(2-3), 494-504. doi:10.1162/jeea.2005.3.2-3.494.

Galor, O., \& Weil, D. N. (1996). The gender gap, fertility, and growth. The American Economic Review, 86(3), 374-387.

Galor, O., \& Weil, D. N. (1999). From Malthusian stagnation to modern growth. The American Economic Review, 89(2), 150-154.

Galor, O., \& Weil, D. N. (2000). Population, technology, and growth: From Malthusian stagnation to the demographic transition and beyond. The American Economic Review, 90(4), 806-828.

Goldin, C. (1995). The U-shaped female labor force function in economic development and economic history. In T. P. Schultz (Ed.), Investment in women's human capital and economic development (pp. 61-90). Chicago, IL: University of Chicago Press.

Greenhouse, L. (2005). Becoming Justice Blackmun: Harry Blackmun's supreme court journey. New York: Times Books.

Henshaw, S. K., Singh, S., \& Haas, T. (1999). The incidence of abortion worldwide international. Family Planning Perspectives, 25, S30-S38. doi:10.2307/2991869.

Heston, A., Summers, R., \& Aten, B. (2006). Penn world table version 6.2. Center for International Comparisons of Production, Income and Prices at the University of Pennsylvania.

Imbens, G., \& Angrist, J. (1994). Identification and estimation of local average treatment effects. Econometrica, 62(2), 467-476. doi:10.2307/2951620.

International Labor Organization. (1997). Economically active population, 1950-2010. Geneva: ILO.

International Labour Organization. (2007). ILO database on labour statistics. International Labour Organization Bureau of Statistics.

Kelley, A. C., \& Schmidt, R. M. (1995). Aggregate population and economic growth correlations: The role of the components of demographic change. Demography, 32(4), 543-555. doi:10.2307/2061674.

Kelly, W. R., \& Cutright, P. (1983). Determinants of national family planning effort. Population Research and Policy Review, 2(2), 111-130. doi:10.1007/BF00141248.

Klerman, J. A. (1999). U.S. abortion policy and fertility. The American Economic Review, 89(2), 261-264.

Levine, P. B., Staiger, D., Kane, T. J., \& Zimmerman, D. J. (1999). Roe v Wade and American fertility. American Journal of Public Health, 89(2), 199-203. doi:10.2105/AJPH.89.2.199.

Mammen, K., \& Paxson, C. (2000). Women's work and economic development. The Journal of Economic Perspectives, 14(4), 141-164.

Medoff, M. H., Dennis, C., \& Bishin, B. G. (1995). Bimodal issues, the median voter model, Legislator's ideology, and abortion. Atlantic Economic Journal, 23(4), 293-303. doi:10.1007/BF02298765.

Murray, M. P. (2006). Econometrics: A modern introduction. Boston: Addison-Wesley.

Peel, J., Potts, M., \& Diggory, P. (1977). Abortion. Cambridge: Cambridge University Press.

Romer, C. D., \& Romer, D. H. (1989). Does monetary policy matter? A new test in the spirit of Friedman and Schwartz. NBER Macroeconomics Annual, 4, 121-170. doi:10.2307/3584969.

Romer, C. D., \& Romer, D. H. (1994). Monetary policy matters. Journal of Monetary Economics, 34(1), 75-88. doi:10.1016/0304-3932(94)01150-8.

Rosenzweig, M. R., \& Schultz, T. P. (1985). The demand for and supply of births: Fertility and its life cycle consequences. The American Economic Review, 75(5), 992-1015. 
Rosenzweig, M. R., \& Wolpin, K. I. (1980). Testing the quantity-quality fertility model: The use of twins as a natural experiment. Econometrica, 48(1), 227-240. doi:10.2307/1912026.

Ross, J., \& Stover, J. (2001). The family planning program effort index: 1999 cycle. International Family Planning Perspectives, 27(3), 119-129. doi:10.2307/2673833.

Singh, S., \& Wulf, D. (1996, December). An overview of clandestine abortion in Latin America. Guttmacher Institute Issues in Brief.

Smith, J. P., \& Ward, M. P. (1985). Time-series growth in the female labor force. Journal of Labor Economics, 3(1), 59-90. doi:10.1086/298076.

Stock, J. H., \& Yogo, M. (2005). Testing for weak instruments in linear IV regression. In D. W. K. Andrews \& J. H. Stock (Eds.), Identification and inference for econometric models: Essays in honor of Thomas Rothenberg. Cambridge: Cambridge University Press.

United Nations. (2002). Abortion policies: A global review. Department of Economic and Social Affairs, Population Division. Accessed 2007, from http://www.un.org/esa/population/publications/abortion/index. htm.

United Nations. (2007). World population prospects: The 2006 revision. United Nations.

World Bank. (2006). World Bank development indicators CD-ROM.

Young, A. (1995). The tyranny of numbers: Confronting the statistical realities of the East Asian growth experience. The Quarterly Journal of Economics, 110(3), 641-680. doi:10.2307/2946695. 